\title{
Comparison of bend angle measurements in fresh cryopreserved cartilage specimens after electromechanical reshaping
}

\author{
Koohyar Karimi*, Dmitriy Protsenko, Edward Wu, Allen Foulad, Cyrus Manuel, Brian Wong \\ From 2nd Scientific Meeting of the Head and Neck Optical Diagnostics Society \\ San Francisco, CA, USA. 23-24 January 2010
}

Cryopreservation of cartilage has been investigated for decades and is an established protocol. However, the reliability and application of cryopreservation of cartilage for use in electromechanical reshaping (EMR) has not been studied exclusively. A system to cryopreserve large amounts of tissue provides a steady source of similar quality cartilage for future experimentation. This will reduce error that may arise from different cartilage stock, and have the potential to maximize efficiency under time constraints. Our study utilizes a unique methodology to cryopreserve septal cartilage for use in electromechanical reshaping studies. Septal cartilages were extracted and placed in one of three solutions (Saline, PBS, and 10\% DMSO by volume in PBS) for four hours in a cold room. Then, each cartilage specimen was vacuumed and sealed in an anti-frost plastic bag and placed in freezer for 1 to 3 week durations. EMR was performed using 2 volts for 2 minutes to create a bend. Bend angle measurements of the cryopreserved cartilage specimens were compared to the bend angles of fresh cartilage which underwent EMR using the same parameters. Results demonstrate that Saline, PBS, and DMSO were effective in cryopreservation, and indicated no significant differences in bend angle measurements. Our methodology to cyropreserve cartilage specimens provides a successful approach for use in electromechanical reshaping studies.

Published: 29 October 2010

doi:10.1186/1758-3284-2-S1-020

Cite this article as: Karimi et al: Comparison of bend angle

measurements in fresh cryopreserved cartilage specimens after

electromechanical reshaping. Head \& Neck Oncology 2010 2(Suppl 1):O20.

Beckman Laser Institute and Medical Centre, Irvine, USA
Submit your next manuscript to BioMed Central and take full advantage of:

- Convenient online submission

- Thorough peer review

- No space constraints or color figure charges

- Immediate publication on acceptance

- Inclusion in PubMed, CAS, Scopus and Google Scholar

- Research which is freely available for redistribution

Submit your manuscript at www.biomedcentral.com/submit
C Biomed Central 